\title{
野球投手の筋厚の非対称性とボールスピードの関係
}

\author{
長谷川 伸，小野 高志
}

\section{The relationship between asymmetric characteristics of muscle thickness and ball speed in baseball pitchers}

\author{
Shin Hasegawa and Takashi Ono \\ 九州共立大学スポーツ学部, †807-8585 福岡県北九州市八幡西区自由ヶ丘1-8 (Faculty of Sports Science, \\ Kyushu Kyoritsu University, 1-8 Jiyugaoka, Yahatanisi-ku,Kitakyushu-shi, Fukuoka 807-8585, Japan)
}

Received: December 7, 2011 / Accepted: February 13, 2012

\begin{abstract}
The primary purpose of this study was to investigate whether the baseball pitchers have asymmetric characteristics of muscle thickness (MT) in upper extremities, trunk, and lower extremities because of repetitive pitching. The secondary purpose of this study was to investigate the relationship between MT and ball speed. Twenty-six college baseball pitchers participated in this study. Twenty-six sites were selected to quantify the asymmetric characteristics of MT. The MT was measured by a B-mode ultrasound. The ball speed, measured by a radar gun, was used to quantify the pitching performance. The MT of forearm, subscapula, and chest in dominant side (pitching side) were significantly greater than those in nondominant side, and the MT of abdomen, lateral abdomen, and anterior thigh in nondominant side were significantly greater than those in dominant side. On the other hand, the MT of forearm in both sides and the MT of lateral abdomen in dominant side were significantly and positively correlated with ball speed. These results suggest that asymmetric muscle thickness in upper extremity, trunk, and lower extremity in baseball pitchers resulted from repetitive pitching, and the MT of forearm and lateral abdomen are related to the ball speed.
\end{abstract}

Jpn J Phys Fitness Sports Med, 61(2): 227-235 (2012)

Keywords : muscle thickness, ultrasound, baseball pitcher, ball speed

\section{緒言}

野球投手の四肢や体幹の形態や機能には，投球側と非 投球側の間に非対称性（以下, 非刘称性）が存在するこ とが知られている，上肢の形態面では，投球側は広背筋 や三角筋を含む肩甲帯全体，前腕部の手関節，手指の屈 筋群に打いて筋肥大が顕著であること年，機能面でも 非投球側と比べると肩関節の内旋筋力, 内転筋力は同等 以上の值を示し ${ }^{4-7)}$, 外旋可動域は大きく, 内旋可動域 は小さいことなどが報告されている ${ }^{1,4,8)}$. 体幹部の形態 面では，第3-4腰椎間の水平断面に抒いて腹部を前腹笳 (腹直筋), 側腹筋 (外腹斜筋, 内腹斜筋, 腹横筋), 後 腹筋（腰方形筋）に分類 ${ }^{9}$ したときの側腹筋と後腹筋の 筋横断面積は非投球側の方が大きく2,10), 機能面でも非 投球側方向への回旋筋力が投球側方向への回旋筋力上り も大きいことが報告されている ${ }^{10)}$ ，さらに下肢の形態面 では大腿部や下腿部の総筋横断面積には差がみられない が, 外側広筋や中間広筋など個別の筋の筋横断面積が非 投球側 (踏込脚)に扔いて大きく ${ }^{2)}$, 機能面では投球側 (軸
脚）の股関節可動域が内旋，外旋，内転，外転において いずれも大きいことが報告されている ${ }^{11)}$. これらの先行 研究に見られるように, 野球投手の身体の形態的, 機能 的な非対称性は上肢では概ね投球側が優位性を示すが, 体幹，下肢では非投球側が優位性を示すものも多く，上 肢とは必ずしも同様の結果は得られていない.

一方, 競技力向上の観点から野球投手のボールスピー ドを決定する要因を明らかにしようとする研究が見られ る. 形態面では全身の除脂肪体重や筋量, さらに部位別 にみると上腕部, 腹部・背部, 大腿部の筋量がボールス ピードと有意な相関を示すことが報告されている ${ }^{12,13)}$. また，機能面においても，肩関節内旋，外旋筋力や肘関 節伸展筋力, 手関節掌屈筋力とボールスピードの間に有 意な相関があることが報告されている ${ }^{14-16)}$ ，これらの研 究はボールスピードを決定する上で特に重要な役割を果 たす身体部位があることを示唆するものであるが，分析 にはいずれも投球側に打ける測定值が用いられている. しかし, ピッチング動作では踏出脚の大腿部から下胴に 流入する力学的エネルギーがボール初速度と有意な相関 
を示すとした島田ら ${ }^{17)}$ の報告に見られるように，力学的 なエネルギーが非投球側の下肢から投球側の上肢へ向 かって流れることが示唆されて抢り, ボールスピードと の関係においても非投球側の方がより重要性を持つ身体 部位が存在する可能性が考えられる.

スポーツ選手の身体に打ける非対称性に関して対照群 を設定した研究では，非競技者には上肢2,3.8)，体幹2,18), 下肢 ${ }^{2}$ の形態的な非対称性が示されないことが報告され ている。服部 ${ }^{199}$ は筋や骨などの非対称性は一側に偏っ た負荷が筋などの軟部組織を不均衡に発達させること や，軟部組織が付着している骨の発達にも影響を与えた ことにより生じたものとしており，身体における筋量の 非対称性の示される部位やその大きさは, 投球動作にお ける力学的なエネルギーの伝達経路や筋への刺激やス卜 レスが大きい身体部位を反映するものと考えられる。ま た，身体全体の筋厚やその非対称性の大きさとボールス ピードの関倸は, ボールスピードの高い選手において顕 著に発達している筋を推察する手掛かりになると考えら れる。，そこで本研究では野球投手を対象に投球側と非投 球側の間に打ける身体各部の筋厚の非対称性を明らかに するとともに，筋厚やその非対称性の大きさとボールス ピードとの関係について検討することを目的とした．

\section{方 法}

被験者 被験者は大学生野球投手 26 名 (年齢19.2 \pm 1.0 歳, 身長 $178.0 \pm 5.0 \mathrm{~cm}$ ，体重 $74.7 \pm 6.2 \mathrm{~kg}$ ）であった。いずれ も高校, 大学を通して投手を専門としているものであ り，投手としての経験年数は $11.2 \pm 1.8$ 年であった，投動 作，打動作に扔いて同方向への捻転運動を行う右投げ右 打ち，左投げ左打ちの者のみを選出した。また，全ての 被験者は研究参加時に扔いて上肢, 体幹, 下肢に障害や 外傷がなく, 全力での投球が可能な状態であった. 被験 者には, あらかじめ研究の目的, 方法, 実験に伴う安全 性を説明し，書面にて実験参加についての同意を得た。 なお, 本研究は九州共立大学倫理委員会の承認を得て実 施した。

形態計測 形態計測の項目は身長, 体重, 除脂肪体重, 骨格筋量, 上肢長, 上腕長, 前腕長, 手長, 下肢長, 大 腿長, 下腿長, 上腕囲, 前腕囲, 大腿囲, 下腿囲の 15 項目である，身長は身長計を用いて $0.1 \mathrm{~cm}$ 単位まで計測 した。体重, 除脂肪体重, 骨格筋量は体成分分析装置 (InBody720, Biospace社製) を用いて測定した。体肢長 の測定にはマルチン式計測器を用い, 測定点間の距離を $0.1 \mathrm{~cm}$ 単位で計測した。 上腕長は肩峰から上腕骨外側上 顆まで，前腕長は橈骨頭から尺骨茎状突起まで，手長は 尺骨茎状突起から中指先端まで, 上肢長は肩峰点から指 先点までとした。また，大腿長は大転子点から脛骨外側
果まで，下腿長は脛骨外側果から脛骨外果まで，下肢長 は床面から大転子点までとした。四肢, 体幹の周径囲 の測定には布製のメジャーを用い，測定点間の距離を $0.1 \mathrm{~cm}$ 単位で計測した。いずれも測定は立位で行い，上 腕囲は上腕長の近位から $60 \%$, 前腕囲は前腕長の近位か ら 30\%, 大腿囲は大腿長の近位から50\%, 下腿囲は下腿 長の近位から $30 \%$ 部位で計測した。各測定は投球側 （D：Dominant）と非投球側（ND：Nondominant）の 両側について実施した。また，下肢に掞ける投球側は軸 脚 (右投手の場合の右脚), 非投球側は踏込脚（右投手 の場合の左脚）とした。

筋厚測定 B モード超音波診断装置（SSD-900,アロカ 社製）および7.5MHzのリニア式プローブを用いて，投 球側と非投球側の前腕部, 上腕前部, 上腕後部, 大腿前部, 大腿後部 (外側), 下腿前部, 下腿後部, 胸部, 前腹部, 側腹部, 肩甲下部, 肩甲棘上部, 肩甲棘下部の13部位（計 26力所）の筋厚を測定した（Fig 1).

上肢，下肢掞よび肩甲下部の測定はAbe et $\mathrm{al}^{20}{ }^{20)} の$ 方法に基づいて実施した，前腕部は前腕長の近位から $30 \%$, 上腕前部，後部は上腕長の近位から $60 \%$, 大腿前 部，後部は大腿長の近位から $50 \%$, 下腿前部，後部では 下腿長の近位から $30 \%$, 肩甲下部は肩甲骨下角の $5 \mathrm{~cm}$ 下方を測定部位とした。また，肩甲棘上部，下部は長谷 川ら ${ }^{3)}$ の方法に基づき, 肩峰後角から肩甲棘内側縁の中 点の位置に打ける肩甲棘の上方 $2 \mathrm{~cm}$, 下方 $2 \mathrm{~cm}$ を測定 部位とした，胸部では島野ら ${ }^{21)} の$ 方法に基づき，仰臥位 にて肩峰点と胸骨上点の中間位㧍よび胸骨上点と胸骨中 点の中間位の交点位置を測定部位とした。前腹部, 側腹 部は久保田ら ${ }^{18)}$ の方法に基づき，前腹部は腱画により左 右それぞれ 4 つに分けられる腹直筋の筋腹の上から 3 番 目（第 3 筋腹）に抢いて白線と外側縁の中間位，側腹部
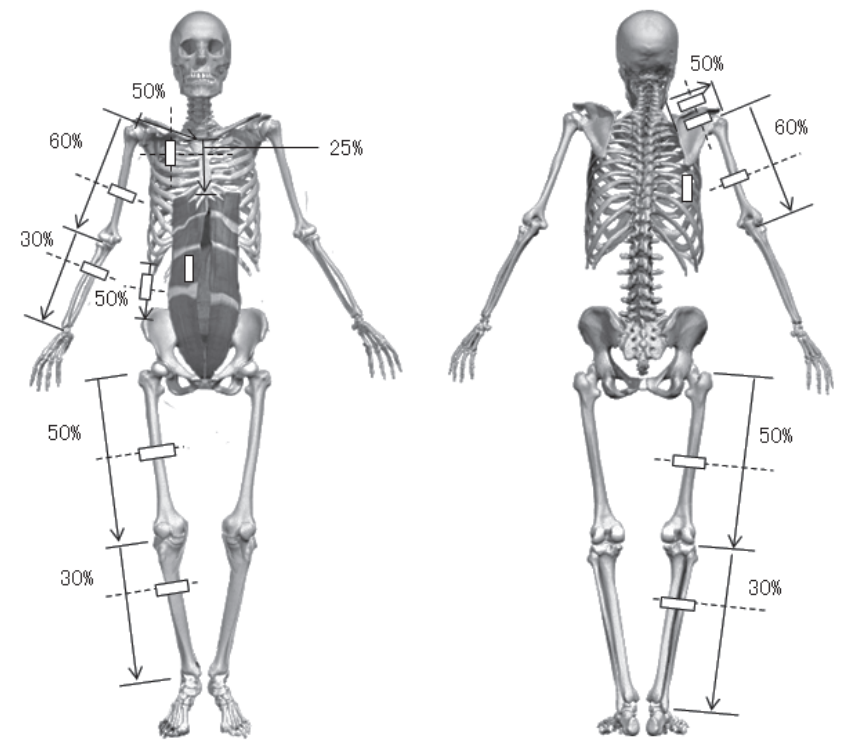

Fig 1. The measurement sites of muscle thickness 
は肋骨と上前腸骨棘との中間位を測定部位とし, 筋厚に 対する呼吸の影響を小さくするため仰臥位にて呼気終末 時に全ての撮影を行った。測定姿勢は先行研究と同様に 前腕部, 上腕前部, 上腕後部, 大腿前部, 大腿後部, 下 腿前部, 下腿後部, 肩甲下部の測定は立位, 肩甲棘上部, 肩甲棘下部の測定は椅座位, 胸部, 前腹部, 側腹部の測 定は仰臥位にて実施した。

撮影した超音波画像は医療用レコーダー（メディキャ プチャーUSB-200, NET-JAPAN社製) を介して画像ファ イルとして取得した後, 画像解析ソフト (Scion Image, Scion Corporation）を用いて筋厚を測定した。筋厚は前 腕部, 上腕前部 - 後部, 大腿前部 · 後部, 下腿前部 - 後 部, 肩甲下部については安部ら ${ }^{22)}$ の方法に基ついて計測 を行った。また, 胸部 ${ }^{21)}$, 前腹部・側腹部 ${ }^{18)}$, 肩甲棘上 部・下部3)についてはそれぞれの先行研究の方法に基づ いて測定を行った。

筋厚測定の対象とした筋は前腕部では手関節屈筋群, 上腕後部では上腕三頭筋, 大腿後部では膝関節屈筋群, 下腿前部では前脛骨筋, 肩甲下部では広背筋, 肩甲棘上 部では棘上筋, 肩甲棘下部では棘下筋, 胸部では大胸筋, 前腹部では腹直筋とした。また，筋厚が複数の筋により 構成され, 超音波画像上明確に区別できる上腕前部, 側 腹部, 大腿前部, 下腿後部については全体の筋厚ととも に個別の筋に対する計測も行った。 上腕前部は上腕二頭 筋と上腕筋, 側腹部は外腹斜筋, 内腹斜筋, 腹横筋, 大 腿前部は大腿直筋と中間広筋, 下腿後部では腓腹筋とヒ ラメ筋に分類して測定を実施した。

ボールスピードの測定 ボールスピードの測定は投手の 競技におけるパフォーマンスを反映させるため, 形態計 測や筋厚測定の後 1 週間以内における実戦形式での投球 を対象とした。 ボールスピードはバックネット後方の同 一位置に設置したドップラー式スピードガン (SSK社製) を用いて測定し，ストライクと判定されたストレートの 投球15球の上位 5 球の平均值を分析に使用した.

統計処理 各測定項目は全て平均值士標準偏差で示し た。投球側と非投球側の非対称性の大きさを表す指標に はVerschuerの平均百分率偏差 $\left(=\frac{D-N D}{D+N D} \times 100\right)$ を用い た．投球側と非投球側の比較には対応のある $\mathrm{t}$ 検定を用 いた。また，各測定值とボールスピードの間の関係，非 対称性の大きさとボールスピードとの関係は相関分析を 行い, ピアソンの相関係数を求めた。いずれも統計的な 有意水準は $\mathrm{p}<0.05$ とした。

\section{結果}

形態計測における上肢と下肢の長径と周径をFig 2 に 示した。投球側と非投球側の比較において，長径ではい
ずれの測定值にも差は示されなかったが，周径では上腕 囲，前腕囲，下腿囲において投球側が有意に高い值を示 した。

筋厚測定における上肢，体幹，下肢の筋厚をFig 3 に 示した。 前腕部, 肩甲下部, 胸部では投球側が有意に高 い值を示し, 前腹部, 側腹部, 大腿前部では非投球側が 有意に高い值を示した（Fig 3-A）。 また，側腹部を構 成する筋では内腹斜筋と腹横筋, 大腿前部を構成する筋 では中間広筋が非投球側において有意に高い值を示した (Fig 3-B).

上肢, 下肢の長径, 周径, 筋量, ならびに全身の筋厚 の非対称性の大きさと方向性をFig 4 に示した. 四の正 方向は投球側優位，負方向は非投球側優位であることを 示している. 周径や筋量では前腕囲や上腕囲, 上肢筋量 において投球側優位の傾向が示された（Fig 4-A）。筋 厚では上肢（前腕部，上腕前部・後部）, 肩部（肩甲棘 上部・下部)，体幹上部 (肩甲下部, 胸部), さらに下腿 部（下腿前部・後部）において投球側優位，体幹下部 (前腹部, 側腹部), 大腿部 (大腿前部・後部) において は非投球側優位の傾向が示された（Fig 4-B).

本研究における被験者全体のボールスピードの平均值 は36.4 $\pm 1.9 \mathrm{~m} / \mathrm{s}$ （最高值 $40.7 \mathrm{~m} / \mathrm{s}$, 最低值 $31.4 \mathrm{~m} / \mathrm{s}$ ）であつ た。 ボールスピードと形態計測值との関係において，身 長や育量では身長 $(r=0.265)$, 体重 $(r=0.425, p<0.05)$, 除脂肪量 $(r=0.432, p<0.05)$, 骨格筋量 $(r=0.447, p<$ 0.05）であり，育量に関する指標においてボールスピー

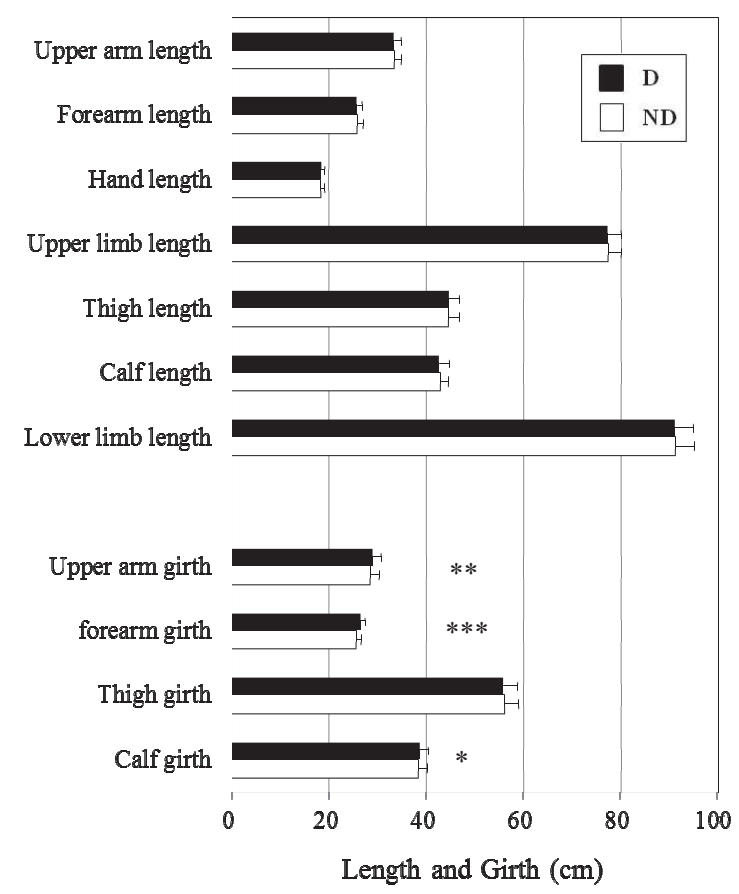

Fig 2. Comparison of length and girth in upper and lower limbs between dominant and nondominant.

$\mathrm{D}$ : dominant, ND : nondominant.

${ }^{*}$ :p $<0.05,{ }^{* *}$ :p $<0.01,{ }^{* * *}$ :p $<0.001$; Significantly different from nondominant. 

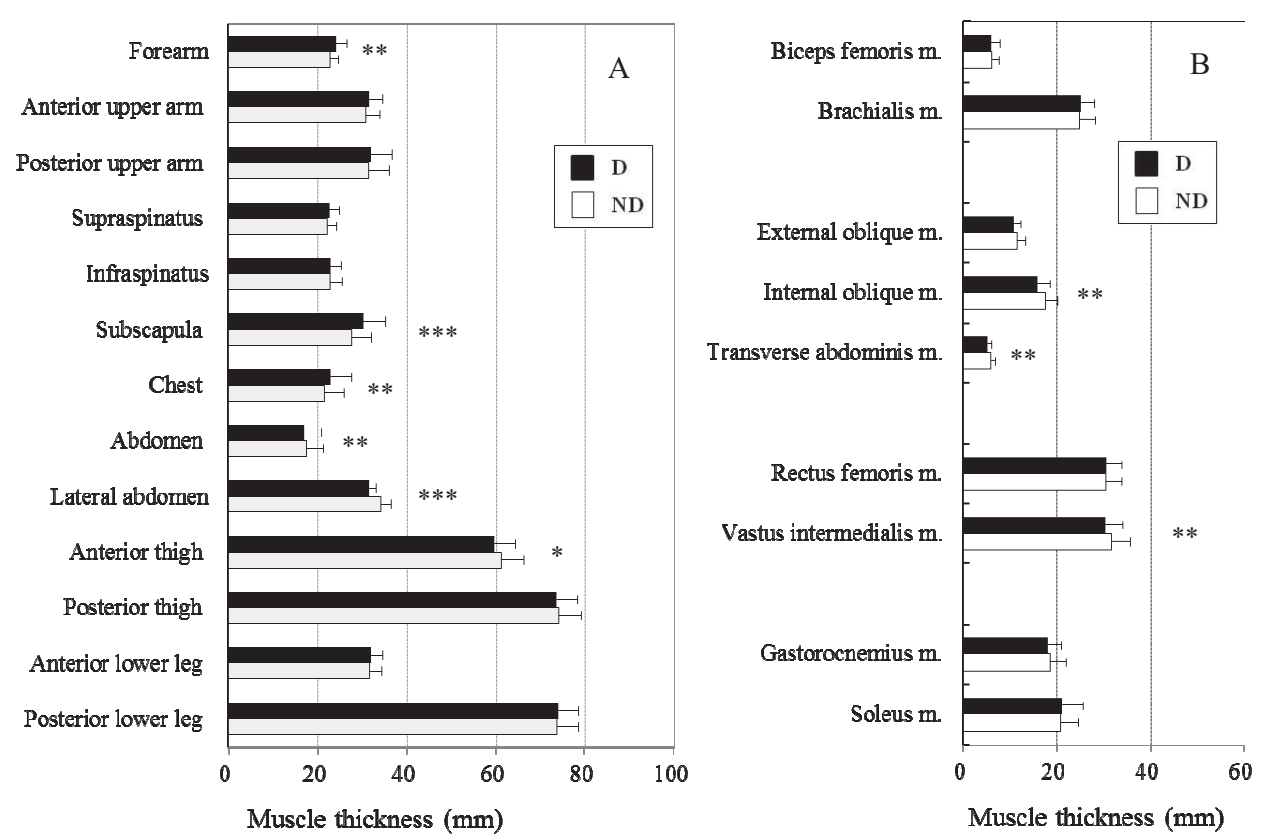

Fig 3. Comparison of the muscle thickness between dominant and nondominant. $\mathrm{D}$ : dominant, ND : nondominant.

${ }^{*}: \mathrm{p}<0.05,{ }^{* *}: \mathrm{p}<0.01,{ }^{* * *}$ : $\mathrm{p}<0.001$; Significantly different from nondominant.

A

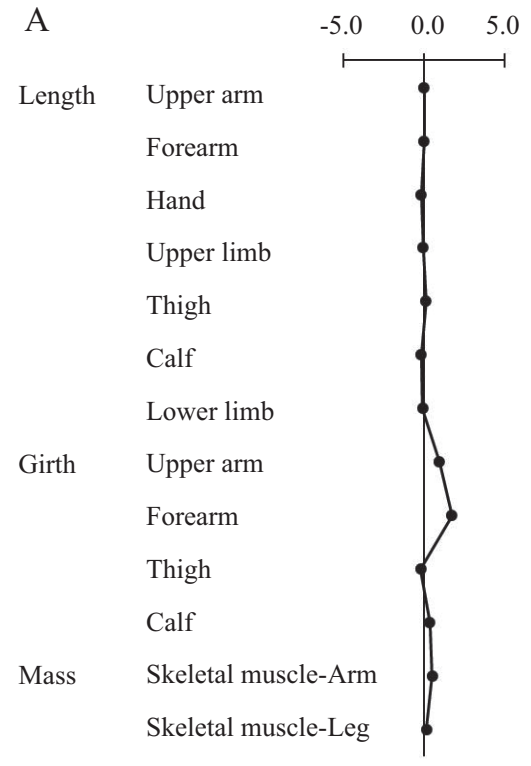

B

Forearm

Anterior upper arm

Posterior upper arm

Supraspinatus

Infraspinatus

Subscapula

Chest

Abdomen

Lateral abdomen

Anterior thigh

Posterior thigh

Anterior lower leg

Posterior lower leg

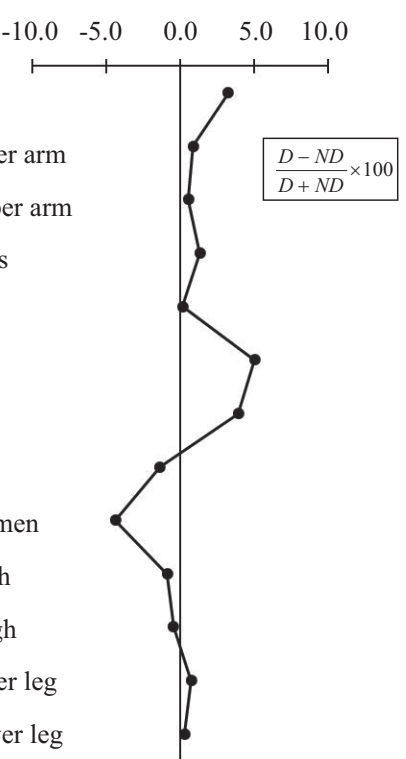

Fig 4. Relationship of the dominant and nondominant side in anthropometric index (A) and muscle thickness (B).

ドと有意な正の相関が示された。また，四肢の長径や周 径に関する指標では投球側の前腕長 $(r=0.460, \mathrm{p}<0.05)$, 前腕囲 $(r=0.399, p<0.05)$, 下腿囲 $(r=0.426, p<0.05)$ がボールスピードと有意な正の相関を示したが，四肢の 長径や周径の非対称性の大きさとボールスピードの間に は有意な相関は示されなかった（Table 1).

ボールスピードと上肢，体幹，下肢の筋厚の関係を部 位別に見ると，投球側の前腕部 $(r=0.492, p<0.001)$,
側腹部（ $\mathrm{r}=0.409, \mathrm{p}<0.05 ）$ および非投球側の前腕部 （r=0.432， p < 0.01）においてボールスピードとの間に 有意な正の相関が示された。 また，筋別に見ると投球側 の上腕筋 $(r=0.435, \mathrm{p}<0.05)$, 内腹斜筋 $(\mathrm{r}=0.441, \mathrm{p}<$ $0.05)$, 非投球側の内腹斜筋 $(r=0.443, \mathrm{p}<0.05)$ に打い てボールスピードと有意な正の相関が示された. しかし, 筋厚における非対称性の大きさとボールスピードの間に はいずれの部位掞よび筋においても有意な相関は示され 
なかった（Table 2).

\section{考察}

投球側と非投球側の非対称性 投球動作は投球腕の肩関 節の水平内転と内旋, 肘関節の伸展, 橈尺関節の回内, 手関節の掌屈を伴う運動である ${ }^{23)}$ 。筋電図学的研究から も投球動作をバックスイングとフォワードスイングの 2 局面に分けたとき, フォワードスイングでは投球側の大 円筋や上腕三頭筋, 橈側手根屈筋や円回内筋に高い活動 が見られることが報告されている24). また, 投球動作を ワインドアップ期, 前期コッキング期, 後期コッキング 期, 加速期, フォロースルー期の 5 つの局面に分けた研 究においても, 加速期には大胸筋, 前鋸筋, 肩甲下筋, 広背筋など肩関節の内旋, 水平内転に貢献する筋に高い 笳活動が見られることが報告されている ${ }^{25)}$. このような 特性を持つ一側に偏った運動を反復することにより, 上 肢には形態的な非対称性が見られるとする報告は，これ までにも数多く行われている. King et al. ${ }^{1)}$ は1960年代 に視診に基づき，投球側では広背筋や三角筋を含む肩甲 帯全体, さらには前腕部の手関節屈筋群に筋肥大が見ら れることを報告しており，その後のMRIを用いて筋量を 定量化した研究からも, 前腕屈筋群, 上腕三頭筋, 三角 筋などにおいて投球側の筋量が大きいことが報告されて きた2,3).

本研究における上肢の筋厚の測定結果は先行研究とよ く一致するものであり, 肩関節の水平内転や内旋を担う 大胸筋や広背筋, 橈尺関節の回内や手関節の掌屈を担う 前腕屈筋群において投球側では非投球側に対する顕著な 筋の肥大傾向が示された。一方, 肘の伸展動作を担う上 腕後部 (上腕三頭筋) の筋厚では両側間の差が見られな かった，上腕三頭筋については先行研究においても投球

Table 1. Correlation coefficients between anthropometric index and ball speed.

\begin{tabular}{|c|c|c|c|c|c|}
\hline & & $\mathrm{D}$ & & ND & $\frac{D-N D}{D+N D}$ \\
\hline \multirow[t]{7}{*}{ Length } & Upper arm & 0.236 & & 0.313 & -0.137 \\
\hline & Forearm & 0.460 & * & 0.192 & 0.341 \\
\hline & Hand & 0.131 & & 0.336 & -0.208 \\
\hline & Upper limb & .0338 & & 0.344 & 0.001 \\
\hline & Thigh & 0.190 & & 0.221 & -0.089 \\
\hline & Calf & 0.383 & & 0.282 & 0.268 \\
\hline & Lower limb & 0.388 & & 0.334 & 0.151 \\
\hline \multirow[t]{4}{*}{ Girth } & Upper arm & 0.248 & & 0.198 & 0.097 \\
\hline & Forearm & 0.399 & * & 0.370 & -0.014 \\
\hline & Thigh & 0.294 & & 0.339 & -0.145 \\
\hline & Calf & 0.426 & * & 0.379 & 0.105 \\
\hline \multirow[t]{2}{*}{ Mass } & Skeletal muscle-Arm & 0.366 & & 0.381 & -0.064 \\
\hline & Skeletal muscle-Leg & 0.375 & & 0.377 & -0.092 \\
\hline
\end{tabular}

Values are mean \pm SD. D : dominant, ND : nondominant. : $\mathrm{p}<0.05$.
側の筋量が上回るとする研究と差はみられないとする 研究の両方が存在し, 見解は分かれている ${ }^{2,26)}$. Hirano and Ikegami ${ }^{26)}$ はプロ野球投手を対象とした研究におい て上腕三頭筋の筋量には両側間の差が見られないことを 報告し, その理由を投球時の肘の伸展動作が高速であり, 时伸筋の最大等尺性筋力に対して低い力発揮しかなさ れていないためであると考察している。また, Feltner and Dapena ${ }^{27)} も$ 加速局面中に発生する肘伸展卜ルクは 小さく, 时の伸展は上腕三頭筋に起因するものではなく, 肩最大外旋位において肘で発生する求心的な関節力によ り伸展モーメントが発生することにより, 时が伸展させ られることにより起こるものとしている。 これらのこと から，投球動作における肘伸展の力発揮が大きいもので はないため, 対側に対して筋肥大が示されなかったもの と考えられる.

また，本研究では周径囲において前腕部や上腕部では 投球側が高い值を示した，前腕囲については先行研究な らびに本研究において投球側の前腕部の筋厚が厚いこと

Table 2. Correlation coefficients between muscle thickness and ball speed.

\begin{tabular}{|c|c|c|c|c|c|}
\hline $\begin{array}{l}\text { Site } \\
\qquad \text { Muscle }\end{array}$ & \multicolumn{2}{|l|}{$\mathrm{D}$} & \multicolumn{2}{|l|}{ ND } & $\frac{D-N D}{D+N D}$ \\
\hline Forearm & 0.492 & $* * *$ & 0.432 & $* *$ & 0.203 \\
\hline Anterior upper arm & 0.219 & & 0.289 & & -0.093 \\
\hline Biceps brachii & -0.059 & & 0.040 & & -0.120 \\
\hline Brachialis & 0.435 & $*$ & 0.360 & & 0.021 \\
\hline \multicolumn{6}{|l|}{ Posterior upper arm } \\
\hline Triceps brachii & 0.057 & & -0.009 & & 0.093 \\
\hline \multicolumn{6}{|l|}{ Supraspinatus } \\
\hline Supraspinatus & 0.378 & & 0.180 & & 0.262 \\
\hline \multicolumn{6}{|l|}{ Infraspinatus } \\
\hline Infraspinatus & 0.298 & & 0.280 & & -0.011 \\
\hline \multicolumn{6}{|l|}{ Subscapula } \\
\hline Latissimus dorsi & 0.060 & & 0.063 & & 0.007 \\
\hline \multicolumn{6}{|l|}{ Chest } \\
\hline Pectoralis major & 0.101 & & 0.031 & & 0.156 \\
\hline \multicolumn{6}{|l|}{ Abdomen } \\
\hline Rectus abdominis & 0.019 & & 0.035 & & -0.064 \\
\hline Lateral abdomen & 0.409 & $*$ & 0.339 & & 0.149 \\
\hline External oblique & 0.278 & & 0.149 & & 0.113 \\
\hline Internal oblique & 0.441 & $*$ & 0.443 & $*$ & 0.067 \\
\hline Transverse abdominis & 0.126 & & 0.162 & & -0.034 \\
\hline Anterior thigh & 0.060 & & 0.213 & & -0.270 \\
\hline Rectus femoris & 0.140 & & 0.115 & & 0.047 \\
\hline Vastus intermedius & 0.046 & & 0.247 & & -0.322 \\
\hline Posterior thigh & 0.193 & & 0.115 & & 0.083 \\
\hline \multicolumn{6}{|l|}{ Anterior lower leg } \\
\hline Tibialis anterior & 0.244 & & 0.142 & & 0.182 \\
\hline Posterior lower leg & 0.382 & & 0.315 & & 0.117 \\
\hline Gastrocnemius & 0.236 & & 0.286 & & -0.129 \\
\hline Soleus & 0.283 & & 0.117 & & 0.297 \\
\hline
\end{tabular}

Values are mean $\pm \mathrm{SD}$. $\mathrm{D}:$ dominant, ND : nondominant ${ }^{*}: \mathrm{p}<0.05,{ }^{* *}: \mathrm{p}<0.01,{ }^{* * *}: \mathrm{p}<0.001$. 
が示されており，筋肥大が大きな要因と考えられる。一 方, 上腕囲については上腕後部の上腕三頭筋, 上腕前部 の上腕二頭筋や上腕筋においても両側間に差が見られな かったことから，筋量の違いだけでは説明することが難 しい. 角田ら ${ }^{2}$ はMRIを用いた画像分析から, 野球投手 の利き腕の尺骨や上腕骨では, 非利き腕に対して大きな 横断面積を示すことを報告し, 投球動作の繰り返しが筋 だけではなく骨の特異的な発達を生じさせた可能性を指 摘している. 本研究では骨に対する計測は行っていない が，骨性の変化をも含んだ結果である可能性も考えられ る。

投球動作における体幹部の働きについては, 踏込脚の 接地前から非投球側の体幹の回旋筋群には伸張性筋収縮 が起こり, その後, 短縮性筋収縮へと変わることで加速 相の中盤にかけて典型的なStretch-shortening cycle運 動が生じるとされている ${ }^{28)}$. 筋電図学的研究においても, 踏込脚の接地後には非投球側の腹直筋, 腹斜筋により高 い筋放電が見られ, 踏込脚接地時に伸張された非投球側 の腹筋群がその後の体幹回旋運動に強く関与している ことが示唆されている ${ }^{29,30)}$. 広義の腹筋は前腹筋, 側腹 筋, 後腹筋の 3 つに区分され, 前腹筋には腹直筋や錐体 筋, 側腹筋には外腹斜筋, 内腹斜筋, 腹横筋, 後腹筋に は腰方形筋が含まれる ${ }^{9)}$. 本研究に执いて非対称性が示 された側腹筋は異なる機能を持つ 3 つの筋で構成され, 外腹斜筋は対側への回旋, 側屈, 屈曲, 内腹斜筋は同側 への回旋，側屈，屈曲，腹横筋は同側への回旋と腹腔内 圧を高める作用を持ち, 投球動作にみられるような体幹 の捻転においては外腹斜筋と内腹斜筋が特に大きなトル クを発揮するとされている ${ }^{31}$. 体幹部の筋の非対称性に ついては野球選手 ${ }^{2,10)}$ ，テニス選手 ${ }^{18)} に$ に扔いても見られ， テニス選手では側腹筋を構成する外腹斜筋と内腹斜筋の 筋厚が非利き腕側において大きいことが報告されてい る ${ }^{18)}$. 本研究では外腹斜筋には非対称性が示されなかっ たが, 内腹斜筋と腹横筋に掞いて非投球側優位の非対称 性が示された。非投球側の外腹斜筋は投球方向とは逆の 回旋運動を行う筋であるのに対して, 内腹斜筋や腹横筋 はいずれも同側への回旋作用を持つ筋であり, 非投球側 に扔けるこれらの筋の作用は投球方向への回旋であるこ とから，側腹筋に見られる非対称性はいずれも投球方向 への回旋動作を繰り返すことにより生じた筋の適応であ ると考えられる。

投球動作に㧍ける下肢の役割については，軸脚（投球 側）はプレートを蹴ることにより体幹などを捕手方向へ 移動させること, 踏込脚（非投球側）はそれを「しっか りと支えること」であるとされ没2，投球動作中に示され る床反力は軸脚では体重の1.0倍, 踏込脚では体重の 1.75 倍であり, 踏込脚においてより大きな筋力発揮が要求さ れる ${ }^{33)}$ 。また，身体を「しっかりと支える」ために踏込
脚の接地後には股関節, 膝関節の伸展筋群にエキセント リックな筋収縮による伸展トルクが発生していること や, 投球数の増加に伴い股関節の伸展トルクが減少し, これを補うために膝関節の伸展卜ルク発揮による仕事量 が増加することなどが報告されている ${ }^{34,35)}$. 本研究では 股関節の伸展卜ルク発揮に貢献すると考元らえる大腿後 部の筋厚には両側間の差が見られなかった，股関節の伸 筋群は下肢の大腿骨の近位に付着する大殿筋や中殿筋, 小殿筋の一部の線維からなるグループと大腿二頭筋，半 腱様筋, 半膜様筋などいわゆるハムストリングスと総称 されるグループからなり, 後者は膝関節伸展位に打ける 股関節伸展作用に有効とされている ${ }^{36)}$. しかし, 投球動 作に扮ける踏込脚は最も大きな股関節伸展卜ルクが発揮 されるボールリリース直前には膝関節が100～110度程度 の屈曲位にあるとされることから ${ }^{34)}$ ， 八ムストリングス の貢献度は低く，大殿筋など大腿骨近位に付着する筋群 の貢献度が高いものと考えられる. 本研究では大殿筋な ど近位に付着する筋群の筋厚の測定を行っていないが, 八ムストリングスの貢献度が相対的に低い姿勢での運動 であることが，大腿後部に执いて筋厚の非対称性が示さ れなかったものと考えられる。一方, 膝関節の伸筋であ る大腿前部，さらにその構成筋である中間広筋では踏込 脚が軸脚に対して大きな筋厚を示したが，大腿直筋には 差が見られなかった。同様の結果は筋横断面積において 外側広筋や中間広筋は踏込脚のほうが大きく, 大腿直筋 には差がないとした角田ら ${ }^{2)}$ の報告にも見られる，大腿 直筋は膝関節伸展に扮いて大腿四頭筋の筋力全体の $1 / 5$ しかなく, 効力は肢位に依存するため股関節屈曲位では 他の 3 筋のほうが有効であるとされている36).このため, 股関節伸展に求ける大腿後部の場合と同様に, 踏込脚の 筋力発揮における関節角度の特異性が踏込脚の大腿直筋 に優位性が見られなかった原因と考えられる。

本研究において筋厚の非対称性が示された部位は, 上 肢と体幹上部においては前腕部, 胸部, 肩甲下部であり, いずれも投球側に優位性が見られた。一方, 体幹下部と 下肢では側腹部, 前腹部, 大腿前部であり, いずれも非 投球側に優位性が見られた（Fig 5)。このことから非対 称性は上肢, 体幹, 下肢のいずれの部位にも示されるが, その優位性は胸郭の下端あたりを境として入れ替わる傾 向にあると考えられる.Myers ${ }^{37}$ は一連の筋群が 1 つの ユニットとして機能するという筋膜の連結という考え方 に基づき, 投球動作のような身体の捻転動作において重 視される 2 つの連結線」を示している。1つは非投球 側の脛骨より大腿筋膜張筋や腸脛勒帯から腸骨, 内腹斜 筋を経て, 投球側の外腹斜筋, 肋骨, 前鋸筋, 肩甲骨, 菱形筋, 頸椎や胸椎に至る身体を螺旋状にとりまく「ラ セン線」と呼ばれる連結線であり，もう1つは「機能線」 と呼ばれる連結線であり, 非投球側の大腿骨から長内転 


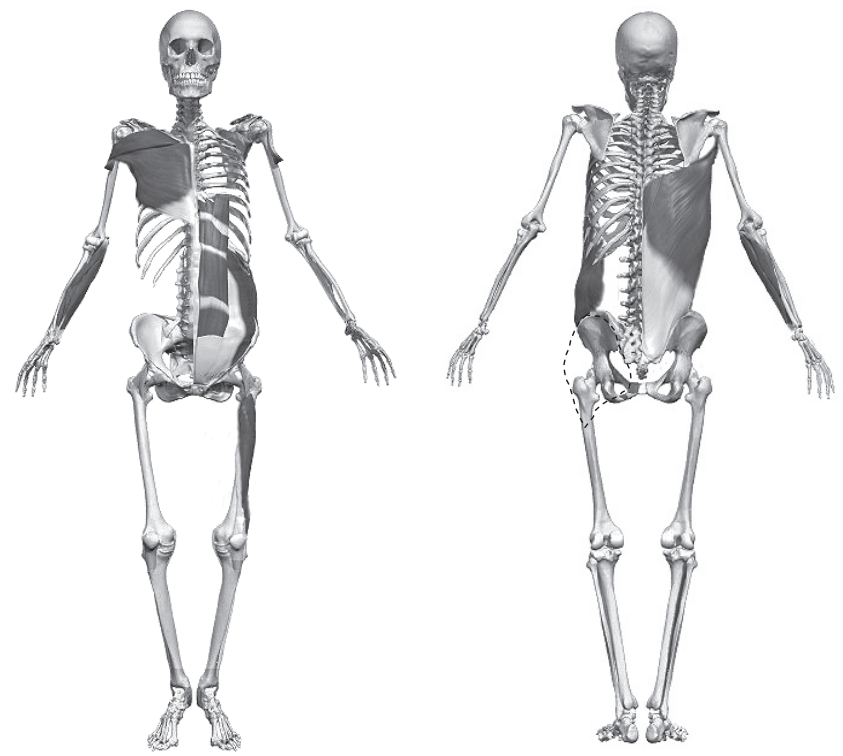

Fig 5. The muscles that have shown to be thicker than the other side.

筋, 恥骨を経て, 投球側の腹直筋, 肋骨, 大胸筋, 上腕 骨に至るものは「前機能線」, 非投球側の脛骨粗面から 膝蓋勒带, 膝蓋骨, 外側広筋, 大腿骨, 大殿筋, 仙骨を 経て投球側の仙骨筋膜, 胸背筋膜, 広背筋, 上腕骨に至 るものは「後機能線」と呼ばれている。本研究において 対側に対して優位性を示した部位を見てみると, Myers の示した「機能線」と多くの共通点を見出すことができ, 野球投手の上肢, 下肢に見られる筋厚の非対称性は, 非 投球側の下肢から投球側の上肢にかけて一連の筋群が協 働し，身体の捻転動作を下肢から上肢へ伝達するための 経路における筋の発達を示したものとも考えられる.

身体各部の筋厚とボールスピードの関係 ボールスピー ドを規定する要因を筋量 $2,12,13)$ や筋力 ${ }^{12,14-16)}$ という観点か ら検討した研究はこれまでにもいくつか見られる，筋量 については体重, 除脂肪量, 全身の筋量, 部位別でみた 上腕部, 大腿部の筋量, さらに大腿部を二分した大腿前 部, 大腿後部の筋量, 腹部・背部の筋量などがボールス ピードと有意な相関を示すことが報告されている ${ }^{12,13)}$. また，筋力については肩関節の内旋，外旋，内転卜ル ク, 肘関節の伸展, 屈曲トルク, 手関節の掌屈トルク, 膝関節の伸展トルクなどがボールスピードと有意な相関 を示すことが報告されている12,14-16) 。本研究においても 体重, 除脂肪量, 骨格筋量など筋量を反映する指標にお いてボールスピードと有意な正の相関が示された。ま た，身体各部の筋厚では両側の前腕部，投球側の側腹部 の筋厚において，さらに筋別にみると両側の内腹斜筋や 投球側の上腕筋においてボールスピードとの有意な相関 が示された。本研究における前腕部の筋厚は複数の筋か ら構成されており超音波画像上での明確な区別は難しい が, 表層より橈側手根屈筋, 円回内筋, 浅指屈筋, 深指
屈筋など前腕の回内, 手関節の掌屈, 手指の屈曲に関 わる筋群の筋厚を示すものである。宮西ら ${ }^{38)}$ は大学生野 球投手のボールスピードに対する貢献度は手関節の掌

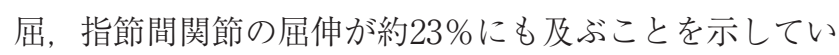
る。また島田ら ${ }^{17)}$ は肘および手関節に伝達される力学的 エネルギーはいずれもボール初速度と高い相関を示すこ とを報告し, 踏込脚の接地からボールリリースまでの手 関節の仕事は負であり, 筋は伸張性収縮をしていること から，手やボールに伝えられるエネルギーの大部分は関 節力パワーに起因し, 肘や肩関節などのより近位部で発 生したパワーが関節や筋, 腱を介して転移したものであ ると述べている ${ }^{17,39)}$. このことから, 投球動作における 手関節や指節間関節の役割はパワーを発生させることよ りも，パワーを伝達することが重要であり，投球側に見 られた前腕部の特異的な発達は投球動作においてパワー を効率よく伝達することに貢献するものであると考えら れる。一方，投球動作において体幹筋は 2 つの役割を持 ち，1つは体幹を捻転させる役割であり，もう1つは体 幹を固定する役割である ${ }^{29,30)}$ 。投球動作時の体幹の捻転 に貢献する側腹筋は解剖学的には非投球側の内腹斜筋や 腹横筋，投球側の外腹斜筋であり，体幹の固定には腹直 筋を含め側腹部の 3 筋全てが関与する ${ }^{31)}$. Hirashima et $\mathrm{al}^{29)}$ は腹直筋がボールリリース時に最大の筋活動を示す のは, 上肢の角運動のために必要な求心力を生み出す役 割であると考察している。本研究において側腹部（特に 内腹斜筋）には非対称性が見られるにも関わらず，両側 の内腹斜筋の筋厚とボールスピードとの間に有意な正の 相関が示されたのは，体幹の回旋だけではなく固定とい う役割の重要性を示すものであるかもしれない.

本研究において投球速度と有意な相関が示された前腕 部の手関節掌屈・手指間関節屈曲筋群, 上腕筋, 内腹斜 筋は大腿部や胸・肩部など筋量が大きく, 大きな関節卜 ルクを生み出すことができる部位に隣接し, 伸張性筋収 縮を伴ったより大きな筋力発揮を行うことにより関節の 固定や力の伝達に貢献する筋群であると考えられる。ま た，いずれも両側間に非対称性が示された筋であるが, 非対称性の程度が大きいほど投球速度が高いという結果 は得られなかった。このことから, 前腕部や側腹部（内 腹斜筋）の筋厚はボールスピードとの関連があると考え られるが，一側だけに過度な筋肥大が見られることが投 球速度向上につながるものではなく, 両側のバランスの よい発達が重要であることが示唆された。

\section{結 論}

本研究では大学生野球投手26名に対して投球側と非投 球側それぞれ13部位の筋厚測定を行い，(1)筋厚の非対称 性の存在部位, (2)筋厚やその非対称性の大きさとボール スピードの関係について以下のような結論を得た。 
1. 身体13部位の中で 6 部位において筋厚の非対称性が 示され，前腕部，肩甲下部，胸部では投球側が非投 球側に対して有意に高い值を示し, 前腹部, 側腹部, 大腿前部では非投球側が投球側に対して有意に高い 值を示した。

2. 筋厚とボールスピードの関係では両側の前腕部, 投 球側の側腹部においてボールスピードとの間に有意 な正の相関が示された。 また，筋別では両側の内腹 斜筋, 投球側の上腕筋の筋厚がボールスピードと有 意な正の相関を示した.

これらのことから，野球投手の身体各部には非投球側 の踏込脚から体幹部（下胴）, 投球側の体幹部（上胴） から上肢にかけて対側に対する筋の肥大傾向が見られる こと, さらに投球動作時に打いて体幹や上肢を安定化さ せる筋群の発達がボールスピード向上にとって重要であ ることが示唆された

\section{参 考 文 献}

1) King, J. W., Brelsford, H. J., and Tullos, H. S. Analysis of the pitching arm of the professional baseball pitcher. Clin Orthop Relat Res, 67: 116-123, 1968.

2）角田直也, 田中重陽, 石塚信之, 青山利春, 岡田雅次, 西 山一行. 投動作パフォーマンスに及ぼす筋形態及び機 能的特性, 国士舘大学体育研究所報, 21: 135-140, 2002.

3）長谷川伸, 館俊樹, 斎藤恵一, 王力群, 加藤清忠. 野球投 手の回旋腱板筋（rotator cuff muscles） と三角筋の MRI法による筋量分析とその筋力特性, 体力科学, 53 : 483-492, 2004.

4) Brown, L. P., S. L. Niehues, Harrah, A.,Yavorsky, P., and Hirshman, H. P. Upper extremity range of motion and isokinetic strength of the internal and external shoulder rotators in major league baseball players. Am J Sports Med, 16: 577-585, 1988.

5) Wilk, K. E., J. R. Andrews, Arrigo, C. A., Keirns, M. A., and Erber, D. J. The strength characteristics of internal and external rotator muscles in professional baseball pitchers. Am J Sports Med, 21: 61-66, 1993.

6) Sirota, S. C., Malanga, G. A., Eischen, J. J., and Laskowski, E. R. An eccentric- and concentric-strength profile of shoulder external and internal rotator muscles in professional baseball pitchers. Am J Sports Med, 25: 59-64, 1997.

7) Ellenbecker, T. S. and Mattalino, A. J. Concentric isokinetic shoulder internal and external rotation strength in professional baseball pitchers. J Orthop Sports Phys Ther, 25: 323-328, 1997.

8) Crockett, H. C., L. B. Gross, Wilk, K. E., Schwartz, M. L., Reed, J., O'Mara, J., Reilly, M. T., Dugas, J. R., Meister, K., Lyman, S., and Andrews, J. R. Osseous adaptation and range of motion at the glenohumeral joint in professional baseball pitchers. Am J Sports Med, 30: 20-26, 2002.

9）森於菟, 小川鼎三, 大内弘, 森富. 腹部の筋, 分担解剖学1.
第11版, 金原出版, 東京, 321-332, 2002

10）後藤篤志, 大川昌宏. 大学軟式野球選手の体幹筋の特 徵に関する研究, NITTAI Sports Training Journal, 1: 19-23, 2005.

11) Robb. A. J., Fleisig, G., Wilk, K., Macrina, L., Bolt, B., and Pajaczkowski, J. Passive range of motion of the hip and their relationship with pitching biomechanics and ball velocity in professional baseball pitchers. Am J Sports Med, 38: 2487-2493, 2010.

12）勝亦陽一, 長谷川伸, 川上泰雄, 福永哲夫. 投球速度と筋 力および筋量の関係, スポーツ科学研究, 3: 1-7, 2006.

13）勝亦陽一, 高井洋平, 太田めぐみ, 佐久間潤, 川上泰雄, 福永哲夫. 大学野球選手にみられる筋量および筋量分 布の特徴が投球スピードに与える影響, スポーツ科学 研究, 4: 75-84, 2007.

14) Pedegana, L. R., R. C. Elsner, Roberts, D., Lang, J., and Farewell, V. The relationship of upper extremity strength to throwing speed. Am J Sports Med, 10: 352354, 1982.

15) Bartrett, L. R., Storey, M. D. and Simons, B. D. Measurement of upper extrimity torque production and its relationship to throwing speed in the competitive athlete. Am J Sports Med, 17: 89-91, 1989.

16) Pawlowski, D. and Perrin. D. Relationship between shoulder and elbow isokinetic peak torque,torque acceleration energy, average power, and total work and throwing velocity in intercollegiate pitchers. Athletic Training, 24: 129-132, 1989.

17）島田一志, 阿江通良, 藤井範久, 川村卓, 高橋圭三. 野球 のピッチング動作における力学的エネルギーの流れ. バイオメカニクス研究, 8: 12-26, 2004.

18）久保田潤, 奥村幸治, 鳥居俊, 福林徹. 大学テニス選手に おける腹筋群の形態的特徵, 日本臨床スポーツ医学会 誌, 17: 30-34, 2009 .

19）服部恒明，ヒトのかたちと運動，大修館書店，東京，7980, 1996.

20) Abe, T., Kondo, M., Kawakami, Y., and Fukunaga, T. Prediction equation for body composition of Japanese adults by B-mode ultrasound. Am. J. Human Biol, 6: 161-170, 1994.

21）島野敬四郎, 内田智子, 安藤佳代子, 高山伸也, 須田憲司, 湯浅景司. 女性投てき選手の筋厚と筋力, 中京大学体育 学論叢, 39: 107-112, 1997.

22）安部孝, 福永哲夫. 超音波が描いた皮下脂肪組織と筋組 織, 日本人の体脂肪と筋肉分布, 初版, 杏林書院, 東京, 91-108, 1994.

23）桜井伸二, 池上康男, 矢部京之助, 岡本敦, 豊島進太郎. 野球の投手の投動作の 3 次元動作解析, 体育学研究, 35: 143-156, 1990.

24）風井訫恭, 熊本水頼, 岡本勉, 山下謙智, 後藤幸弘, 丸山 宣武. 野球の投動作 (オーバーハンドスロー)における 上肢・上肢帯筋群の作用機序, 体育学研究, 21: 137-144, 1976.

25) Gowan, I. D., F. W. Jobe, Tibone, J. E., Perry, J., Moynes, D. R. A comparative electromyographic analysis of the shoulder during pitching. Professional versus amateur pitchers. Am J Sports Med, 15: 586-590, 1987. 
26) Hirano, Y. and S. Ikegawa. Laterality in upper limb composition and maximal isometric strength of elbow joint of baseball players. 東京大学教養学部体育学紀要, 21: 20-24, 1987.

27) Feltner, M. and J. Dapena. Dynamics of the shoulder and elbow joins of the throwing arm during a baseball pitch. Int. J. Sports Biomech, 2: 235-259, 1986.

28）宮西智久. 野球の投 - 打動作の体幹捻転研究-SSC理論 に着目してーバイオメカニクス研究, 13: 149, 2009.

29) Hirashima M., Kadota H., Sakurai S., Kudo K., Ohtsuki $\mathrm{T}$. Sequential muscle activity and its functional role in the upper extremity and trunk during overarm throwing. J Sports Sci, 20: 301-10, 2002.

30) Watkins, R. G., Dennis, S., Dillin, W. H., Schnebel, B., Schneiderman, G., Jobe, F., Farfan. H, Perry, J., Pink, M. Dynamic EMG analysis of torque transfer in professional baseball pitchers. Spine, 14: 404-8, 1989.

31) 大久保雄, 金岡恒治. 体幹の捻転動作の医学的基礎. バ イオメカニクス研究, 13: 125-129, 2009.

32）高橋圭三. 投動作を助ける脚のはたらき. 体育の科学, 56: 174-80, 2006.

33) MacWilliams, B. A., Choi, T., Chao, E. Y. S., McFarland,
E. G. Characteristics ground-reaction forces in baseball pitching. Am J Sports Med, 26: 66-71, 1998.

34）島田一志, 阿江通良, 藤井範久, 結城匡啓. 野球のピッチ ング動作における体幹および下肢の役割に関するバイ オメカニクス的研究. バイオメカニクス研究, 4: 47-60, 2000.

35）平山大作, 藤井範久, 小池関也, 阿江通良. 野球投手の投 球数の増加による下肢関節の力学的仕事量の変化 体力 科学, 59: 225-32, 2010.

36) Kapandji, A. I. (塩田悦二訳), カパンジー機能解剖学 II, 医歯薬出版, 東京, 44, 2010.

37) Myers, T. W. (松下松雄訳),アナトミー・トレイン, 医 学書院, 東京, 25-176, 2009.

38）宮西智久, 藤井範久, 阿江通良, 功力靖雄, 岡田守彦. 野 球の投球動作におけるボール速度に対する体幹および 投球腕の貢献度に関する 3 次元的研究. 体育学研究, 41 : 23-37, 1996.

39）宮西智久, 藤井範久, 阿江通良, 功力靖雄, 岡田守彦. 野 球の投球動作における体幹および投球腕の力学的エネ ルギーフローに関する 3 次元解析. 体力科学, 46: 55-68, 1997. 